\title{
Implementasi Pembiayaan Pertanian Akad Salam Studi Kasus KSM-KUB Jaya Amanah
}

\author{
Zainal Arifin ${ }^{*}$ \\ Eliana Wulandari² \\ Tuti Karyani ${ }^{3}$ \\ 1,2,3 Fakultas Pertanian Universitas Padjadjaran, Indonesia \\ *email: zainal.arifinskd@gmail.com \\ Diterima: April 2021; Disetujui: September 2021; Dipublish: Oktober 2021
}

\begin{abstract}
Abstrak
Permasalahan utama dalam kegiatan usahatani yaitu masih kurangnya modal untuk memenuhi kebutuhan input-input produksi. Pembiayaan syariah dapat dipilih menjadi solusi dikarenakan kesesuaiannya dengan karakteristik pertanian. Lembaga Keuangan Mikro Syariah dapat dijadikan solusi terbaik untuk merealisasikan pembiayaan syariah pertanian ke petani-petani secara langsung. Penelitian ini bertujuan untuk mengetahui penerapan akad salam pembiayaan pertanian di KSM Jaya Amanah di Desa Mekarjaya, Kecamatan Pacet, Kabupaten Bandung. Pendekatan penelitian dirancang dengan kualitatif melalui metode studi kasus. Perolehan data bersumber dari wawancara mendalam kepada informan. Hasil penelitian mengambarkan bahwa beberapa tahapan yang perlu dilakukan dalam program pembiayaan pertanian di KSM Jaya Amanah, seperti Survei ke ke rumah petani, Menganalisis karakter petani, Menganalisis keuangan calon petani anggota (pendapatan dan pengeluarannya), Survei sawah calon petani anggota (menghitung luasnya, menganalisis potensinya), Briefing, Persetujuan dan tanda-tangan kontrak, Serah terima uang, dan Serah terima panen. Dampak penerapan akad salam pada KSM Jaya Amanah sangat dirasakan oleh petani, pemberian modal sesuai dengan kebutuhan petani dan hasil produksi dijual kepada pihak lembaga dengan harga di atas tengkulak atau bandar sesuai dengan kesepakatan antara kedua belah pihak.
\end{abstract}

Kata Kunci: pertanian, salam, pembiayaan.

\begin{abstract}
The main problem in farming activities is the lack of capital to meet the needs for production inputs. Sharia financing can be chosen as a solution because of its suitability with agricultural characteristics. Sharia Microfinance Institutions can be the best solution for realizing agricultural sharia financing directly to farmers. This study aims to determine the implementation of the agricultural financing salam contract at KSM Jaya Amanah in Mekarjaya Village, Pacet District, Bandung Regency. The research approach was designed qualitatively through the case study method. The data were obtained from in-depth interviews with informants. The results of the study illustrate that there are several steps that need to be carried out in the agricultural financing program at KSM Jaya Amanah, such as Survey to farmhouses, Analyze farmer characters, Analyze the finances of prospective member farmers (income and expenditure), Survey of rice fields prospective member farmers (calculating the area, analyzing the potential), Briefing, Approval and contract signing, Handover of money, and Handover of harvest. The impact of implementing the salam contract on KSM Jaya Amanah is felt by farmers, providing capital according to farmers' needs and production products sold to institutions at a price above the middleman or dealer in accordance with the agreement between the two parties.
\end{abstract}

Keywords: agriculture, salam contract, financing 
JURNAL AGRICA Vol.14 No.2/Oktober 2021

Available online http://ojs.uma.ac.id/index.php/agrica 10.31289/agrica.v14i2.5083
ISSN 1979-8164 (Print)

ISSN 2541-593X (Online)

\section{PENDAHULUAN}

Secara global keuangan syariah mengalami perkembangan dan antusias sangat baik di berbagai benua, seperti Asia, Australia, Afrika, Eropa, Canada dan Timur Tengah. Lembaga keuangan syariah merupakan sistem perbankan berbasis Islam yang sangat populer di dunia, yang saat ini mencapai U\$ 882 bilion. Berdasarkan laporan Islamic Finance Outlook tahun 2020 wilayah Timur Tengah, Afrika dan Asia Selatan (MEASA) mengalami peningkatan dalam industri perbankan syariah dengan nilai lebih dari \$2,1 triliun, didorong oleh popularitas yang semakin meningkat. Total aset di wilayah MEASA 25\% dari aset perbankan di GCC, hal ini menunjukkan perbankan Islam menjadi penting secara sistemik di negara-negara tersebut. (Ratings,2020).

Berdasarkan laporan Otoritas Jasa Keuangan (2019) Pertumbuhan dana, takaful, sukuk dan aset di perbankan syariah dunia juga mengalami peningkatan setiap tahunnya dimana pada akhir tahun 2018 mencapai \$2,1, yang menunjukkan keberadaan lembaga keuangan syariah dibutuhkan oleh masyarakat dunia dalam meningkatkan perekonomian secara mikro dan makro.

Kawasan Asia Tenggara menjadi salah satu pusat yang mengalami perkembangan yang cukup pesat di sektor perbankan syariah diantara kawasan ASEAN yang lain. Indonesia dan Malaysia menjadi penggerak perkembangan industri perbankan syariah di kawasan Asia Tenggara. Malaysia merupakan negara yang mengalami perkembangan industri perbankan syariah cukup pesat, saat ini pangsa pasar mencapai $26 \%$ dari total aset perbankan nasional. (Bank Sentral, Dewan Layanan Keuangan Islam, Eikon, S\&P Global Ratings, 2020)

Menurut OJK (2019), Indonesia mayoritas penduduknya beragama Islam, dengan meningkatnya jumlah kelas menengah, maka semakin tinggi ghirah untuk mengembangkan ekonomi syariah di Indonesia. Awal kebangkitan ekonomi syariah diawali dengan beroperasinya Bank Muamalat pada tahun 1992 kemudian berkembang beberapa bank syariah dan pendirian Unit Usaha Syariah (UUS) dari beberapa bank konvensional. Pada tahun 2020 jumlah bank syariah sebanyak 14 dan 20 Unit Usaha Syariah yang beroperasi di wilayah Indonesia. Total aset di sektor keuangan syariah di Indonesia mencapai U\$D 86 miliar, mengalami peningkatan sebesar U\$D 4 miliar pada tahun 2018. Peningkatan ini menempatkan Indonesia pada posisi ke 7 dengan total aset terbesar di dunia. Berdasarkan Annual Report Global Islamic Finance Development Indicator tahun 2019, Indonesia mengalami peningkatan posisi dari periode sebelumnya (OJK,2019)

Menurut Antonio (2001) jenis pembiayaan syariah terbagi menjadi dua tujuan. Pertama, pembiayaan produktif, yang diperuntukkan dalam memenuhi kebutuhan usaha, seperti perdagangan dan investasi. Kedua, pembiayaan konsumtif, bertujuan dalam memenuhi kebutuhan sehari-hari (konsumsi) maupun pribadi.

Berbagai tantangan yang harus dihadapi oleh lembaga syariah antara lain 
masih kecilnya porsi pembiayaan yang menggunakan akad bagi hasil, masih terdapat pembiayaan bermasalah, yang perlu diperhatikan oleh lembaga pembiayaan yang mengalami masalah dalam pembiayaan tidak lancar, terutama dalam penyaluran dana ke UMKM. Selain itu juga terbatasnya penyaluran pembiayaan kepada usaha skala kecil. Lembaga keuangan syariah pada umumnya menyalurkan dana kepada lembaga-lembaga yang besar (Ginting, 2011).

Hasil penelitian Ashari dan Saptana (2016) mengemukakan bahwa pembiayaan syariah merupakan salah satu solusi alternatif dalam sektor usaha, investasi dan lainnya, karena lembaga pembiayaan syariah mempunyai kelebihan dalam produk-produk yang bervariatif dan bertahan pada krisis ekonomi dan moneter serta tidak menerapkan sistem interest (bunga)

Asaad (2011), mengemukakan hasil penelitiannya mengenai pemanfaatan lembaga pembiayaan syariah dalam sektor pertanian. Perbankan syariah mempunyai peranan penting dalam mendukung pembangunan ekonomi nasional, khususnya dalam sektor pertanian. Sektor pertanian merupakan sumber utama mayoritas masyarakat di Indonesia, sudah seharusnya peran lembaga syariah dapat ikut andil dalam meningkatkan kesejahteraan. Berikut strategi peranan lembaga pembiayaan syariah dalam pembiayaan usahatani: 1) Mengembangkan kantor lembaga keuangan syariah di daerah mayoritas petani, 2) Memberikan pembiayaan sesuai dengan syariat Islam yang lebih besar kepada usaha pertanian, 3) Melakukan pemasaran mengenai produk pembiayaan syariah di daerah mayoritas penduduknya bermata pencarian dari sektor pertanian, 4) Memberikan pembiayaan kepada usahatani secara utuh.

Kelompok Swadaya Masyarakat (KSM) Jaya Amanah merupakan lembaga pemberdayaan masyarakat yang mempunyai program Rumah Pembiayaan Pertanian (RPP), Pemberdayaan Masyarakat dan Pendampingan Petani untuk Kesejahteraan. Program yang dilakukan lembaga KSM Jaya Amanah menerapkan sistem akad salam dalam menjalankan program tersebut.

Pembentukan kelompok ini disebabkan oleh kurangnya lembaga sumber pembiayaan petani dalam memperoleh modal dalam memenuhi kebutuhan input produksi usahatani. sehingga mayoritas penduduk melakukan akses modal ke tengkulak. Anggapan masyarakat ketika melakukan pengajuan ke lembaga keuangan mempunyai prosedur serta administrasi yang rumit. sehingga petani memperoleh pinjaman dari tengkulak yang prosedurnya tidak rumit, hanya bermodalkan kepercayaan.

Mayoritas penduduk di sekitar lembaga berprofesi sebagai petani, peternak dan pengrajin yang hasil dari produksi dijual ke tengkulak dengan harga yang lebih rendah dari harga pasar. Penjualan ke tengkulak dilakukan untuk melunasi modal yang sudah dipinjam. Walaupun harga yang diterima sangat kecil namun petani tetap melakukan transaksi untuk melunasi pinjaman tersebut. 
Permasalahan-permasalahan ini membuat beberapa masayarakat membentuk kelompok swadaya masyarakat dalam memberikan solusi bagi petani dalam mengatasi permasalahan mendasar yang sering dihadapi oleh kalangan petani yaitu permodalan. Saat ini lembaga KSM Jaya Amanah sudah banyak melakukan kegiatan dalam membantu masyarakat sekitar khususnya bagi petani.

Program yang sudah dijalankan mempunyai pengaruh serta berdampak bagi masyarakat sekitar, khususnya bagi anggota. Pembiayaan diluncurkan oleh lembaga KSM Jaya Amanah sesuai dengan kebutuhan petani yang mengajukan pembiayaan. Berdasarkan uraian sebelumnya tujuan dari penelitian ini mendeskripsikan penerapan akad pembiayaan pertanian dengan skema akad salam pada KSM Jaya Amanah.

\section{METODE PENELITIAN}

Penelitian ini merupakan penelitian kualitatif dengan studi kasus menggunakan teknik analisis data kualitatif deskriptif. Penelitian kualitatif deskriptif dominan menggunakan analisis dengan pendekatan induktif, landasan teori dimanfaatkan sebagai sumber, agar fokus penelitian sesuai dengan fakta di lapangan (Ali 2002). Teknik pengumpulan data dilakukan melalui observasi langsung ke KSM Jaya Amanah di Desa Mekarjaya, Kecamatan Pacet, Kabupaten Bandung dan wawancara dengan pengurus inti KSM-KUB Jaya Amanah.

\section{HASIL DAN PEMBAHASAN}

KSM-KUB Jaya Amanah merupakan suatu Lembaga Keuangan Mikro Syariah yang dibina langsung oleh LAZ Al-Azhar dan berfungsi untuk membantu pembiayaan usaha UMKM, pertanian, dan peternakan. Latar belakang dibentuknya KSM-KUB Jaya Amanah di Desa Mekarjaya Kecamatan Pacet didasarkan pada hasil survei terkait praktik riba dan ijon yang masih sangat kental, sehingga perlu segera diberi bantuan agar praktik riba dan ijon tidak semakin merugikan masyarakat desa sekitar.

KSM-KUB Jaya Amanah berdiri pada tanggal 4 Mei tahun 2014. KSM-KUB Jaya Amanah awalnya beranggotakan sebanyak 30 orang untuk bidang UMKM karena UMKM adalah sasaran para rentenir untuk menawarkan pinjaman modal yang bunganya merugikan warga. Selanjutnya, pembiayaan berlanjut ke bidang peternakan, dan setelah peternakan berjalan lancar, LAZ Al-Azhar menitipkan dana untuk membantu petani padi dengan program Rumah Pembiayaan Pertanian (RPP). Walaupun berjalan sangat perlahan karena sistem riba dan ijon masih kental di masyarakat, namun semakin lama semakin terlihat hasilnya bahwa program RPP lebih menguntungkan daripada rentenir atau ijon yang dapat dilihat melalui pertambahan jumlah anggota sebanyak lebih dari 100 orang dari tahun ke tahun.

KSM Jaya Amanah menerapkan pemberdayaan dan pembinaan kepada 
anggota dengan beberapa kegiatan. Pihak lembaga KSM Jaya Amanah melakukan kegiatan untuk menambah wawasan anggota, seperti entrepreneur dan budidaya pertanian, pelatihan dilakukan sesuai dengan kebutuhan anggota. Rapat Anggota yang bertujuan mengevaluasi kegiatan yang telah dilakukan, sehingga dapat menjadi bahan perbaikan untuk kegiatan selanjutnya. Pemberdayaan KSM Jaya Amanah berdampak positif bagi semua anggota baik dari segi ekonomi dan pemahaman. Pemberdayaan melalui produk pembiayaan yang disalurkan KSM meringankan anggota untuk membeli kebutuhan input produksinya, sedangkan pemberdayaan melalui pelatihan dapat menambah wawasan anggota untuk kegiatan usaha di sektor pertanian dan perdagangan.

\section{Program Pembiayaan Pertanian di KSM Jaya Amanah}

Salah satu LKMS di Indonesia yang menjalankan kegiatan pembiayaan pertanian dengan prinsip syariah ialah Kelompok Swadaya Masyarakat Jaya Amanah (KSM-KUB Jaya Amanah) di Desa Mekarjaya, Kecamatan Pacet, Kabupaten Bandung. KSM-KUB Jaya Amanah merupakan LKM Syariah yang dibina oleh LAZ Al-Azhar dan menerima dana sosial dari CIMB Niaga Syariah. KSM ini lebih maju diantara 26 LKM lain yang dibentuk oleh LAZ Al-Azhar di kota-kota lain. Hal tersebut dikarenakan capaian-capaian KSM-KUB Jaya Amanah baik dalam aspek non-ekonomi maupun ekonomi yang diantaranya ialah anggota KSM-KUB telah menjalankan usahanya secara syariah, pengelolaan struktur organisasi berfungsi secara efektif dan pencatatan pembukuan keuangan tersusun rapi, perubahan perilaku sosial masyarakat yang tadinya konsumtif menjadi produktif, menjadi lokasi studi banding untuk lembaga sosial, pendidikan, dan bisnis, aset meningkat, seluruh anggota dapat menyisihkan pendapatannya untuk menabung guna persiapan di masa yang akan datang, sebagian besar anggota telah mencapai kemandirian usahanya dan tidak mengalami kesulitan dalam memenuhi kebutuhan hidupnya, pendapatan anggota meningkat, dan harga jual gabah menjadi meningkat. Salah satu program LAZ Al-Azhar yang dikelola oleh KSM-KUB Jaya Amanah ialah program pembiayaan pertanian yang bernama Rumah Pembiayaan Pertanian (RPP). Rumah Pembiayaan Pertanian merupakan program yang bertujuan untuk kesejahteraan petani dan ketahanan pangan. Berdasarkan pernyataan KSM-KUB Jaya Amanah, 15 orang dari 54 petani anggota terhitung sudah mencapai kemandirian usahanya.

Terdapat beberapa tahap yang perlu dilakukan dalam program pembiayaan pertanian sebelum KSM-KUB Jaya Amanah menyetujui pembiayaan kepada petani, yaitu:

1. Survei ke ke rumah petani

Sebelum menentukan petani tersebut dapat mengikuti pembiayaan atau tidak, pengurus atau perwakilan dari KSM Jaya Amanah akan melakukan survei terlebih dahulu ke rumah calon petani anggota tersebut. Hal ini dimaksudkan untuk melihat lingkungan sekitar tempat tinggalnya dan hubungan sosial anggota tersebut dengan orang-orang $\mathrm{di}$ 
sekitarnya. Selama survei dilakukan, pihak KSM-KUB Jaya Amanah akan benar-benar menganalisis kehidupan petani tersebut. Tujuan dilakukannya survei ini juga sebagai salah satu pertimbangan lembaga dalam memberikan pembiayaan kepada calon penerima.

Uraian sebelumnya sejalan dengan pandangan Jureid (2016) menyatakan bahwa perlu dilakukannya kunjungan atau survei dua kali sebelum pembiayaan dicairkan kepada nasabah. Hal ini merupakan aspek yang cukup penting untuk mengurangi risiko yang akan terjadi dan menyiapkan aksi mitigasi apabila terjadi risiko.

2. Menganalisis karakter petani

Selama kunjungan berlangsung pihak KSM Jaya Amanah melakukan analisis pada karakter calon petani anggota menggunakan prinsip 5C (character, capacity, capital, collateral dan condition of economic).

a) Character (sifat atau watak) merupakan suatu keyakinan bahwa sifat/ watak dari calon nasabah yang akan diberikan pembiayaan benarbenar dapat dipercaya, karena ukuran dalam kemauan nasabah untuk membayar kewajibannya.

b) Capacity (kemampuan) melihat kemampuan nasabah dalam bidang bisnis yang dihubungkan dengan kemampuannya dalam menjalankan usahataninya, semakin baik calon nasabah, maka kemampuan dalam mengembalikan pembiayaan yang disalurkan akan berdampak kepada pembiayaan yang akan diberikan. c) Capital (modal) adalah penggunaan modal yang efektif, dapat dilihat dari laporan keuangan (neraca dan laporan laba rugi) dengan melakukan pengukuran seperti likuiditas dan solbabilitas, jika calon nasabah memilih jumlah modal sendiri yang cukup, maka kemungkinan besar proposal pembiayaan yang diajukan kelembaga pembiayaan akan diterima. Namun kenyataan dilapangan petani tidak melakukan pencatatan. Pihak lembaga KSM melakukan wawancara kepada calon nasabah dalam perhitungan modal yang akan digunakan, sehingga kebutuhan biaya tergambarkan secara rinci.

d) Collateral (agunan atau jaminan) adalah barang jaminan yang diserahkan oleh calon nasabah kepada bank sebagai agunan atas pembiayaan yang diberikan, jaminan disini merupakan pengaman (back up) atas risiko yang mungkin terjadi atas tidak terbayarnya pembiayaan yang diberikan sesuai dengan diperjanjikan. Penerapan jaminan yang dilakukan anggota yaitu dengan cara melukan penabungan dana ke KSM berupa tabungan harian dan bulanan tanpa ada batasan nominal. Bila terjadi gagal panen maka uang tabungan tersebut dapat dijadikan jaminan.

e) Condition of economy (kondisi perekonomian) adalah gambaran kondisi ekonomi negara pada saat permohonan pembiayaan, apabila 
kondisi sangat kondusif yaitu kondisi makro ekonomi dan mikro ekonomi cukup baik maka biasanya perbankan lebih mudah mempertimbangkannya. Dalam menilai pembiayaan, hendaknya juga dinilai kondisi ekonomi sekarang dan kemungkinan dimasa yang akan datang sesuai sektor usaha masing-masing serta prospek usaha dari sektor yang dijalankan. Penilaian prospek bidang usaha yang dibiayai hendaknya benarbenar memiliki prospek yang baik, sehingga kemungkinan terjadinya pembiayaan tersebut bermasalah relatif kecil.

Hal ini dilakukan untuk menganalisis kesanggupan dan kemampuan petani tersebut untuk mengikuti seluruh rangkaian pembiayaan syariah pertanian. Hal yang paling penting di sini ialah kesiapan, pemahaman dan kemampuan petani mengikuti peraturan dan syarat-syarat dalam akad salam itu sendiri.

3. Menganalisis keuangan calon petani anggota (pendapatan dan pengeluarannya)

Petani yang akan dibiayai harus memenuhi syarat bahwa pengeluarannya tidak boleh lebih besar dari pendapatannya, jika pengeluaran lebih besar, maka petani tersebut belum sanggup untuk mengatur modal berjumlah terbatas yang nantinya diberikan KSM untuk usahanya. Hal tersebut dikarenakan jika nanti akad berjalan, petani akan kesulitan untuk membayar kembali pembiayaan yang KSM Jaya Amanah berikan.
Sejalan dengan penelitian Iski et al (2015) menuangkan bahwa pendapatan dari usahatani merupakan salah satu pertimbangan lembaga pembiayaan dalam memberikan pembiayaan, hal ini dikarenakan apabila pendapatan dari usahataninya bisa memenuhi kebutuhan konsumtif dan modal, maka pihak lembaga pembiayaan akan dapat memberikan pembiayaan.

KSM Jaya amanah berperan sebagai salah satu pemberi modal untuk membiayai input produksi, sehingga produsen dapat meningkatkan produksinya. Bila diasumsikan bila petani anggota terkendala dalam permodalan, sehingga tidak dapat memenuhi kebutuhan input produksi, dengan adanya KSM sebagai pembantu pembiayaan modal dapat memenuhi kebutuhan input. Beberapa penelitian (Nwaru et al. 2011, Rosmiati. 2012, dan Saleem. 2011) yang menguraikan ketersediaan lembaga pembiyaan memberikan kesempatan bagi petani untuk memenuhi kebutuhan input produksi, yang akhirnya akan meningkatkan produksi dan pendapatan (Sumelius et al, 2011 dan Bauer, 2013).

4. Survei lokasi usaha calon petani anggota (menghitung luasnya, bangunan, menganalisis potensinya).

Survei lokasi usaha dilakukan untuk menghitung luas lahan, tempat yang dimiliki petani tersebut, potensi lahannya, rata-rata hasil produksi dan penjualannya agar KSM Jaya Amanah dapat menganalisis kebutuhan tambahan modal usahatani untuk calon petani anggota tersebut. Hasil penelitian Krishna et al. (2014) yang menguji 
faktor-faktor yang mempengaruhi luas lahan dimana hasil uji membuktikan bahwa luas lahan merupakan faktor yang signifikan terhadap produksi. Menurut Assis et al (2014) bahwa luas lahan merupakan satu-satunya faktor yang memiliki efek yang signifikan terhadap pendapatan bulanan pada petani, jadi jika luas lahan meningkat maka pendapatan petani akan meningkat.

\section{Briefing}

Syarat untuk menjadi anggota seutuhnya ialah, perlu mengikuti terlebih dahulu pembinaan melalui pengajian kelompok selama 2 bulan yang diadakan 1 bulan sekali. Jadi, calon anggota akan di briefing untuk menjadi anggota dan siap mengikuti pembinaan dari pengurus yang tujuannya untuk kemandirian ekonominya secara berkelanjutan.

Hal ini sejalan dengan penelitian yang dilakukan Handriyadi dan Wulandari (2017) hasil penelitian menyatakan bahwa keanggotaan kelompok tani membantu petani dalam meningkatkan kesempatan akses pembiayaan dari berbagai sumber pembiayaan, dengan menjadi anggota kelompok tani, petani memiliki akses yang lebih baik terhadap lembaga pembiayaan.

6. Persetujuan dan tanda-tangan kontrak

Pengurus inti KSM-KUB Jaya Amanah akan berunding untuk menentukan terkait disetujui atau tidaknya petani tersebut untuk ikut dalam program pembiayaan pertanian. Jika telah ditentukan setuju, maka pihak
KSM-KUB Jaya Amanah akan mengatur jadwal untuk bertemu dengan petani tersebut dan membicarakan tentang keseluruhan akad yang akan dijalankan mulai dari syarat-syaratnya, SOP, dan diskusi jika ada hal yang petani kurang paham tentang pembiayaan syariah atau masalah usahatani padi. Jika petani sudah sangat paham, maka akan dilakukan tanda tangan kontrak.

Berdasarkan hasil penelitian Prayoga (2018) pembiayaan pertanian yang lebih optimal dapat dicapai bila terbentuk lembaga khusus yang menangani pembiayaan pertanian. Lembaga ini dapat dibentuk dengan kerja sama yang sinergi antar berbagai pihak. BMT merupakan pilot project dari model strategis lembaga pembiayaan pertanian.

7. Serah terima uang

Ketika tiba waktunya tanam, pihak KSM-KUB Jaya Amanah dan petani akan mulai menjalankan akad salam. Pihak KSM-KUB Jaya Amanah berperan sebagai pembeli produk dan petani sebagai penjual. Pembayaran dari KSMKUB Jaya Amanah dilakukan di muka dan waktu penyerahan barangnya, harga jual, kualitas, dan kuantitas barang sesuai kesepakatan bersama. Setelah itu petani akan mulai melakukan penanaman padi dengan dana dari KSMKUB Jaya Amanah dan memberikan hasil produksinya di akhir ketika waktu panen tiba.

8. Serah terima panen

Ketika tiba waktunya padi panen, pihak KSM-KUB Jaya Amanah akan mengingatkan petani anggota untuk mempersiapkan gabah kering yang akan 
diberikan kepada KSM sesuai dengan kuantitas dan kualitas yang disepakati. Jika petani tidak dapat memberikan barang sesuai permintaan, maka petani dapat menggantinya dalam bentuk uang dengan nilai yang sama seperti barang yang diminta.

\section{Penerapan Akad Salam Pembiayaan Pertanian di KSM Jaya Amanah}

Pelaksanaan pembiayaan syariah pertanian di KSM-KUB Jaya Amanah dilakukan melalui program Rumah Pembiayaan Pertanian (RPP). Pelaksanaan program ini menggunakan produk pembiayaan syariah $B a^{\prime} I$ as-Salam antara petani dengan KSM-KUB Jaya Amanah. Selain itu, bagi hasil dari penjualan melalui KUB (tempat penjualan produk pertanian yang berasal dari akad Bai' as-Salam) antar pengurus RPP dari KSM-KUB Jaya Amanah. Program ini diawali dengan penyaluran dana zakat dari bank syariah kepada LAZ Al-Azhar dan kemudian LAZ Al-Azhar menyalurkan dana tersebut kepada KSM-KUB Jaya Amanah untuk dimanfaatkan. Tiap petani anggota wajib melakukan kegiatan menabung yang dibagi menjadi tiga tabungan yaitu tabungan wajib awal, tabungan per bulan, dan tabungan sukarela yang bertujuan untuk berjagajaga jika ke depannya hasil pertanian tidak memungkinkan untuk membayar sesuai jumlah yang disepakati. Selain itu juga terdapat dana tabarru atau asuransi kesehatan untuk berjaga-jaga jika terdapat anggota yang sakit. Jumlah tabungan dan dana tabarru ditentukan berdasarkan kesepakatan bersama oleh anggota. Proses alur pembiayaan akad salam di KSM Jaya Amanah diuraikan pada Gambar 1.

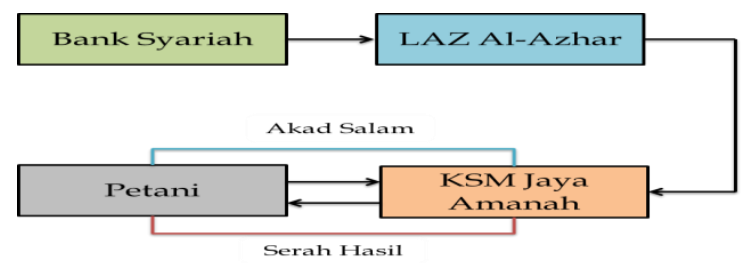

Gambar 1. Skema Akad Salam Pembiayaan Pertanian di KSM Jaya Amanah

Akad salam dipilih sebagai akad yang digunakan di KSM Jaya Amanah, karena kesesuaian dengan permasalahan utama petani terkait kebutuhan modal dan karakteristik pertanian di Desa Mekarjaya. Kondisi petani kebanyakan memperoleh modal dari rentenir, tengkulak atau bandar. Sistem pengembalian pembayaran setelah panen (yarnen) kepada sumber modal yang menerapkan sistem interest (bunga). Sejalan dengan penelitian Shafiai dan Moi (2015) mengungkapkan bahwa sektor pertanian berpandangan perbankan syariah merupakan pembiayaan yang fleksibel bagi sektor pertanian.

Penerapan akad salam di KSM Jaya Amanah, dengan cara modal diberikan kepada petani untuk kebutuhan pembelian input kegiatan usahatani. Petani diharuskan menjual hasil produksi pertanian ke lembaga dengan harga lebih tinggi daripada harga di tengkulak atau bandar. Ketika terjadi penurunan harga waktu panen pihak lembaga tetap membayar dengan harga kesepatakan awal, sehingga petani memperoleh pendapatan lebih tinggi. Sejalan denga penelitian Pamikatsih dan Latif (2020) menyatakan bahwa anggota Bank Wakaf Mikto Al-Ihya Baitul Aqof Cilacap yang 
dibantu permodalan berdampak kepada peningkatan usahatani dengan kepastian penjualan harga produksi taninya.

Hermansyah dan Khoerulloh (2020) menerangkan akad salam merupakan akad jual beli seperti akad murabahah. Namun perbedaan terletak pada sistem pembayaran dan penyerahan objek yang ditransaksikan. Pada akad salam, modal atau biaya diberikan di awal, namun barang akan diterima pada waktu tertentu, sesuai kesepakatan di antara kedua belah pihak. Menurut Antonio (2001) akad salam biasanya diaplikasi pada sektor pertanian, dengan jangka waktu 2-6 bulan.

Menurut Widiana and Annisa (2018), akad salam dinilai dapat meningkatkan kapasitas produksi petani untuk menghasilkan produk lebih banyak dan meningkatkan pendapatannya, hal ini dikarenakan selain jual beli dengan pembeli dimana harga, kualitas dan kuantitas barangnya sudah ditetapkan bersama di awal, petani juga dapat menjualnya ke pihak lain ataupun untuk konsumsi sendiri.

Penentuan harga sudah disepakati antara petani dan KSM Jaya Amanah ketika waktu pemberian pembiayaan di awal. Qusthoniah (2016) mengemukakan akad salam merupakan transaksi dimana barang yang akan diperjualbelikan belum ditransaksikan dan pembeli melakukan pembayaran di muka sedangkan barang diserahkan di kemudian hari sesuai dengan kesepakatan di antara kedua belah pihak.

Saat ini KSM Jaya Amanah mempunyai lahan dan perternakan domba sendiri, sehingga anggota dapat memanfaatkan lahan yang ada dengan cara bergantian memanfaatkannya sesuai dengan arahan dari pengurus. Anggota kelompok sangat merasakan dengan adanya lembaga KSM Jaya Amanah, seperti pengadaaan lahan serta pihak lembaga membeli produk pertanian anggota dengan harga yang sesuai kesepakatan. Sejalan dengan penelitian Muttaqien (2020) menyatakan bahwa KSM Pelita Jampang Gemilang memberikan bantuan berupa sumbangan, pinjaman serta pendampingan dalam upaya meningkatkan kesejahteraan anggota serta masyarakat.

\section{SIMPULAN}

Implementasi pengunaan akad salam KSM Jaya Amanah berupa pemberian modal sesuai kebutuhan petani, kemudian hasil produksi dijual kepada pihak lembaga dengan harga kesepakatan diawal. Penerapan akad salam dapat dirasakan petani anggota KSM Jaya Amanah di Desa Mekarjaya, Kecamatan Pacet, Kabupaten Bandung. Dampak yang dirasakan pihak lembaga membantu petani dalam permodalan, pengembalian dan pendampingan sehingga sangat bermanfaat dirasakan petani. Ketika terjadi gagal panen pihak lembaga tetap mendampingi dan memberikan keringanan kepada anggotanya. Pengurus lembaga KSM Jaya Amanah aktif melakukan kegiatan pelatihan dan pengajian, sehingga ilmu budidaya dan ilmu agama juga didapatkan oleh anggota.

\section{DAFTAR PUSTAKA}

Ali, H. M. Sayuthi. (2002). Metodologi Penelitian Agama: Pendekatan Teori dan Praktek. PT Raja Grafindo 
JURNAL AGRICA Vol.14 No.2/Oktober 2021

Available online http://ojs.uma.ac.id/index.php/agrica 10.31289/agrica.v14i2.5083

Persada.

Antonio, Muhammad Syafi'i. (2001). Bank Syariah: Dari Teori Ke Praktik. Gema Insani.

Asaad, Mhd. 2011. "Peningkatan Peranan Perbankan Syariah Untuk Pembiayaan Usaha Pertanian." MIQOT: Jurnal Ilmu-Ilmu Keislaman 35(1):113-27. doi: 10.30821/miqot.v35i1.134.

Ashari., Saptana. 2016. Prospek Pembiayaan Syariah untuk Sektor Pertanian. Jurnal Forum Penelitian Agro Ekonomi. Volume 23, No.2 : 132-147.

Assis, K., Nurul, A., Amizi Mohammad. 2014. Relationship Between Socioeconomic Factors, Income and Productivity of Farmers : A Case Study On Pineapple Farmers. International Journal of Research in Humanities, Arts and Literature. 1 (2). pp 67-78.

Bauer, S., Ibrahim, AH. 2013. Acces to Micro Credit and its Impact on Farm Profit Among Rural Farmers in Fryland of Sudan. Journal of Agricultural Science 2 (3): 88-102.

Ginting, N, F, H, 2011. "Manajemen Pemasaran." Jurnal Manajemen Pemasaran 22:69-81.

Handriyadi, I., Wulandari, E. 2017. Keanggotaan Kelompok Tani dan Kaitannya dengan Akses Terhadap Sumber Pembiayaan Usahatani Pisang di Kabupaten Cianjur. Jurnal Agribisnis dan Sosial Ekonomi Pertanian (AGRICORE). Vol.2, No. 2, Hal : 291-357.

Hermansyah, I., Khoerulloh, A, K. 2020. Konsep Ba'i Salam dan Implementasinya dalam Mewujudkan Ketahanan Pangan Nasional. Jurnal Iqtisadiya : Ilmu Ekonomi Islam. Vol. 7. No. 14.

Iski, N., Kusnadi, N., Harianto. 2015. Pengaruh Kredit Terhadap
Pendapatan Petani Kopi Arabika di Kabupaten Aceh Tengah Provinsi Aceh. Jurnal Manajemen \& Agribisnis. Vol.12. No.2: 132-143. DOI: 10.17358/JMA.13.2.13

Jureid. 2016. Manajemen Risiko Bank Islam (Penanganan Pembiayaan Bermasalah dalam Produk Pembiayaan pada PT. Bank Muamalat Cabang Pembantu Panyabungan. Jurnal Analytica Islamica. Vol. 55, No.1 : 81-107.

Otoritas Jasa Keuangan (OJK). 2019. Statistik Pebankan Syariah. Jakarta.

Krishna, H., Koirala, A,K., Mishra., Smarendy, M. 2014. Impact of Land Ownership On Producivity and Efficiency of Rice Farmers : A Simulated Maximum Likelihood Approach. The Agricultural and Applied Economics Associations (AAEA) Annual Meeting.

Muttaqien, M, K. 2020. Strategi LAZNAS Al-Azhar dan KSM Binaanya dalam Memberdayakan Pelaku Usaha Mikro. Jurnal Musykat. Vol.3 No.1

Nwaru J, Ubon C, Essien A and Onuoha RE. 2011. Determinats of Informal Credit Demand and Supply Among Food Crop Farmers in Akwa Ibom State, Nigeria. Journal Rural Community Development 6 (1) : 129139.

Pamikatsih, M., Latif, E, A. 2020. Potensi Pengembangan Produk Pembiayaan Akad Salam di Bank Wakaf Mikro AlIhya Baitul Aqof Cilacap. Jurnal Sketsa Bisnis Vol.7, No. 2. Pages 106119.

https://jurnal.yudharta.ac.id/v2/ind ex.php/SKETSABISNIS/index

Prayoga, Adistiar. 2018. Desain Strategi Pembiayaan Pertanian di Perdesaan Jawa Timur Berbasis Daya Saing 
BMT. Jurnal of Halal Product and Research (JHPR) Vol. 01, No. 02.

Qusthoniah, D. I. Perbankan. 2016. "Analisis Kritis Akad Salam di Perbankan Syariah." Jurnal Syariah v No 1:11.

Rosmianti, M. 2012. Pengaruh Kredit terhadap Prilaku Ekonomi Rumah Tangga Petani Padi Sawah : Aplikasi Model Ekonomi Rumah Tangga Usahatani. Jurnal Manajemen Teknologi. 11 (2): 208-224.

Ratings, S\&P Global. 2020. "Islamic Finance Outlook." spglobal.com/ratings.

Saleem MA. 2011, Source and Uses of Agrocultural Credit by Famers in Dera Ismail Khan (District) Khyber Pakhtonkhawa. Pakistan. European Journal Business and Management 3 (3): 111-122.

Shafiai, Muhammad Hakimi Mohd, and
Mohammed Rizki Moi. 2015. "Financial Problems among Farmers in Malaysia: Islamic Agricultural Finance as a Possible Solution." Asian Social Science 11(4):1-16. doi: 10.5539/ass.v11n4p1.

Sumelius J, Islam KM, Zahidul, Sipilainen, Timo. 2012. Access to Microfinance : Does it Matter for Profit Efficiency Among Small Scale Rice Farmers in Bangladesh? The EAAE Congress Change and Uncertainty Challenges for Agriculture. Food an Natural Resources. Zurich, Switzerland.

Widiana, Widiana, and Arna Asna Annisa. 2018. "Menilik Urgensi Penerapan Pembiayaan Akad Salam pada Bidang Pertanian di Lembaga Keuangan Syariah di Indonesia." Muqtasid: Jurnal Ekonomi Dan Perbankan Syariah 8(2):88. doi: 10.18326/muqtasid.v8i2.88-101. 